\title{
Perspectives of the development of complex interdisciplinary hydrological and geocryological research in the North-East of Russia $^{*}$
}

O. M. Makarieva ${ }^{1,2}$, N. V. Nesterova ${ }^{1,2,3}$, A. A. Ostashov ${ }^{1}$, A.A.Zemlyanskova ${ }^{1,2}$, V.E.Tumskoy ${ }^{4,7}$, L.A.Gagarin ${ }^{4}$, A.A.Ekaykin ${ }^{2,8}$, A. N.Shikhov ${ }^{6}$, V. V.Olenchenko ${ }^{5}$, I. I. Khristoforov ${ }^{4}$

${ }^{1}$ Melnikov Permafrost Institute of the Siberian Branch of the Russian Academy of Sciences, Northeastern Research Permafrost Station, 16, ul. Portovaya, Magadan, 685000, Russian Federation

${ }^{2}$ St. Petersburg State University, 7-9, Universitetskaya nab., St. Petersburg, 199034, Russian Federation

${ }^{3}$ State Hydrological Institute, 23, 2-ia liniia V. O., St. Petersburg, 199004, Russian Federation

${ }^{4}$ Melnikov Permafrost Institute of the Siberian Branch of the Russian Academy of Sciences, 36, ul. Merzlotnaya, Yakutsk, 677010, Russian Federation

${ }^{5}$ Trofimuk Institute of Petroleum Geology and Geophysics of the Siberian Branch of the Russian Academy of Sciences, 3, pr. Akademika Koptiuga, Novosibirsk, 630090, Russian Federation

${ }^{6}$ Perm State University, 15, ul. Bukireva, Perm, 614990, Russian Federation

${ }^{7}$ Lomonosov Moscow State University, 1, Leninskie Gory, Moscow, 119991, Russian Federation

${ }^{8}$ Arctic and Antarctic Research Institute, 38, ul. Beringa, St. Petersburg, 199397, Russian Federation

For citation: Makarieva, O. M., Nesterova, N. V., Ostashov, A. A., Zemlyanskova, A. A., Tumskoy, V.E., Gagarin, L. A., Ekaykin, A. A., Shikhov, A. N., Olenchenko, V. V., Khristoforov, I. I. (2021). Perspectives of the development of complex interdisciplinary hydrological and geocryological research in the North-East of Russia. Vestnik of Saint Petersburg University. Earth Sciences, 66 (1), 74-90.

https://doi.org/10.21638/spbu07.2021.105

Climate warming and anthropogenic impact are causing transformation of geocryological conditions in the river basins of Northeast Russia. Changes in the thickness of the active layer, configuration of taliks, types of landscapes and other factors lead to the transformation of water exchange processes between surface and groundwater runoff. This is manifested in the seasonal redistribution of the components of the water balance, accelerated melting of aufeis, and change in the ratio of waters of different genesis in the structure of river runoff. As a result, natural and anthropogenic risks that affect the safe and efficient development of infrastructure and socio-economic processes are increasing. At the same time, the system of observations developed in the Soviet period has been practically destroyed in the region. This paper offers a vision of organizing complex multidisciplinary research to assess and project changes in the conditions of underground and surface water interaction in natural and disturbed river

* The study was supported by the Russian Geographical Society (project 26/2019-I) and Russian Foundation for Basic Research (projects 19-55-80028, 19-35-90090 and 20-05-00666).

(C) St. Petersburg State University, 2021 
basins of the cryolithozone of Northeast Russia, including for solving applied problems, based on permafrost, hydrology, hydrogeology, landscape science and geophysics with applications of remote sensing and field research integrated through mathematical modeling methods. To achieve this goal, natural and disturbed landscapes will be identified using remote sensing data, and key areas will be selected for detailed research. Geophysical and drilling works will be carried out within the sites to establish permafrost-hydrogeological conditions, monitoring stations will be equipped to determine hydrogeological, hydrometeorological and geocryological characteristics, including sampling for isotopic and hydrogeochemical studies. As the main key sites, we propose using the area of the Kolyma Water-Balance Station and the site of the Anmangynda aufeis, where long-term observation series were carried out in the $20^{\text {th }}$ century. Field data will become the basis for improving the mathematical model of runoff formation, considering the relationship between groundwater and river runoff in the conditions of permafrost. Mathematical modeling will make it possible to quantitatively analyze the water balance of rivers considering various factors, and project water availability both for specific industrial facilities and for the region as a whole.

Keywords: water exchange processes, permafrost, river runoff, active layer, talik, suprapermafrost waters, underground runoff, aufeis, geophysics, remote sensing, mathematical modeling, monitoring, isotopes, climate change, anthropogenic disturbances, Northeast Russia.

\section{Introduction}

Northeast Russia is an important strategic resource base, and according to the development plans of the Russian Federation it will soon become one of the most dynamically developing regions of Russia in the permafrost zone. Climate change is listed as one of the main external challenges in the forecast of long-term socio-economic development of the Russian Federation for the period up to 2030. In this regard, it becomes relevant to study the interactions and responses of all components of the natural environment to climate change and anthropogenic impacts.

At present, the Arctic and adjacent territories are subject to climate change that is unprecedented in historical time. This is true both in terms of the degree of climate change as well as in terms of its effects on the environment and built infrastructure. The average annual temperature in the region is growing twice as fast as the global average, having a significant impact on all components of the environment (Assessment report..., 2008; Holmes et al., 2013).

Observations of the permafrost temperature in Russia also show its increase in the last 20-30 years (Romanovsky et al., 2010). Degradation of the cryolithozone, changes in the thickness of the active layer, the configuration of taliks, landscape types, and other factors lead to the transformation of process interactions between surface and underground runoff. This is manifested in the seasonal redistribution of water balance components, acceleration of aufeis melting, and changes in the ratio of water of different genesis in the river flow structure. Direct and indirect evidence of such changes is observed in various regions of the world (Yoshikawa et al., 2003; Osterkamp, 2005; Walvoord and Striegl, 2007; Åkerman and Johansson, 2008; Harris et al., 2009; Quinton et al., 2011; Shepelev, 2011; Brutsaert and Hiyama, 2012; Hinzman et al., 2013; Jepsen et al., 2013; Fedorov et al., 2014; Tregubov et al., 2020).

The mechanisms of interaction between surface and underground runoff, water-bearing rocks, and permafrost are variable and are largely determined by landscape characteristics. Quantitative estimates of the permafrost response and the impact of the active layer 
dynamics on the relationship between surface and groundwater and the runoff formation in the future remain uncertain due to the nonlinear nature of interactions between climate and permafrost landscapes (Burn and Nelson, 2006; Tananaev et al., 2016; Laudon et al., 2017; Makarieva et al., 2019).

At the same time, the anthropogenic impact associated with the industrial and infrastructural development of the Northern territories is increasing, including the development of mineral deposits, construction of roads, power lines and other linear structures, industrial facilities and settlements, construction of hydraulic structures (bridges, water intakes, dams, etc.). All these works have an impact on natural landscapes and the processes occurring within them.

Climate change contributes to increasing natural and anthropogenic risks that affect the safe and efficient development of infrastructure and socio-economic processes in the cryolithozone (Selin et al., 2011; Streletsky et al., 2012; Grebenets et al., 2013).

On the territory of Northeast Russia, permafrost has a continuous distribution in the Arctic region, and is discontinuous in coastal areas. Water exchange between surface and underground waters occurs almost exclusively along sub-stream taliks, leading to the formation of numerous aufeis (Alekseev, 2016; Makarieva et al., 2019). Currently, there are only a few studies indicating that the aufeis regime has changed significantly over the past 30 years, which directly reflects changes in the water exchange system of surface and underground runoff in the region. Presumably, this change is due to an increase in the share of permafrost runoff and the dynamics of underchannel taliks due to climate warming, but there is currently no direct evidence for this. In addition, a significant change in the system of water exchange in river valleys is expected, where for almost a century there has been a large-scale change in the structure of riverbed deposits resulting from gold mining, a deep change in geocryological conditions during freezing of gold-mining polygons, and anthropogenic changes in talik zones and water exchange processes. In general, the dynamics of aufeis formations and runoff changes in the Northeast, including those with anthropogenic causes, directly determine (i) the profitability of gold mining, which is the basis of the economy of the region, (ii) the risks of operating the road network, which is largely associated with river valleys, (iii) the operating mode of reservoirs, and (iv) water supply to settlements. Therefore, the scientific study of changes in the water exchange system of the Northeast and their projections for the near future is an urgent task for the development of the territory of the Northeast. Coordinated interdisciplinary efforts in field monitoring, studying processes at various scales, and developing methods for modeling water exchange processes are necessary for science-based forecasts of future changes in the cryolithozone and the early development of methods for adapting all parts of human life to such changes.

It is important that research should be conducted based on data which has already been obtained in a stationary climate, supplemented by modern observations in a changing climate.

This paper outlines the prospects for the development of complex permafrost-hydrological sites, including restoring the scientific base of the region developed in the Soviet period, in order to implement a set of interdisciplinary studies aimed at studying the mechanisms of interaction and forecasting water exchange of underground and surface runoff in the cryolithozone of Northeast Russia in a changing climate with associated industrial development. 


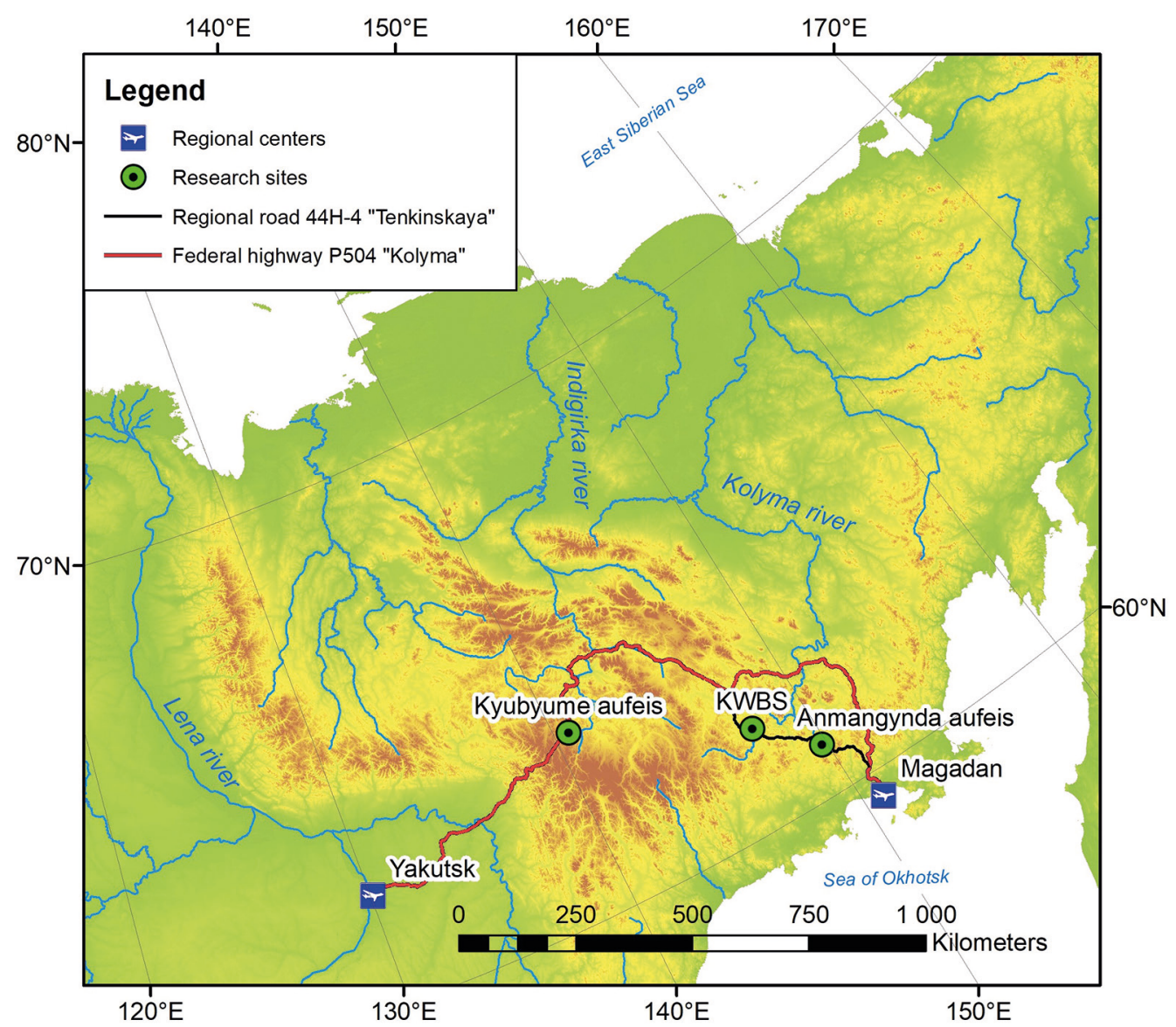

Fig. 1. The study area and prospective research objects. (Digital elevation model obtained from the site (USGS Data Site, n. d.) was used as a geographic basis for building maps.)

There are unique scientific sites where monitoring of hydrological and cryogenic processes typical for the entire region of the mountain territory of Northeast Russia (Magadan region) has been carried out for decades. Among them are the Kolyma Water-Balance Station (KWBS) (Stokovoe village), which operated during the period 1948-1997, as well as the Anmangynda aufeis station (25 km from Ust-Omchug), where observations were made from 1962 to the end of the 1990s. Such sites with a long series of observations do not exist in any other northern country (Fig. 1).

\section{Research key sites}

\subsection{The Kolyma Water-Balance Station (KWBS)}

The Kolyma Water-Balance Station (KWBS) is located in the upper reaches of the Kolyma River, in a mountainous area (elevation 830-1690 m), in the zone of continuous permafrost. The average annual air temperature is approximately $-12^{\circ} \mathrm{C}$, and the amount of precipitation ranges from 250 to $440 \mathrm{~mm}$ per year. Most of the territory is covered 
with rocky talus, thickets of cedar elfin and larch woodlands. The thickness of permafrost reaches $400 \mathrm{~m}$, the depth of summer thawing ranges from $20 \mathrm{~cm}$ in swampy lowlands to $3 \mathrm{~m}$ in goltsy landscapes. The runoff formation processes are representative of the vast territory of the Upper Kolyma and adjacent regions of Northeast Russia.

The KWBS operated ten hydrological gauges in catchments ranging from $0.27 \mathrm{~km}^{2}$ to $21.6 \mathrm{~km}^{2}$, two meteorological sites, 55 rain gauges, more than 20 permafrost meters, several hydrogeological wells, evaporation, water balance and runoff sites, and conducted regular snow-measuring surveys and experimental studies of hydrological and permafrost processes from 1948 to 1997. The station data are systematized and described in detail by Makarieva et al. (2018).

\subsection{The Anmangynda aufeis}

Aufeis are important elements of the hydrological system of the cryolithozone of the Northeast. Their development is associated with the discharge of both underground and surface waters, so the response of aufeis to climate change is different depending on the type of source water. In recent decades, the variability of aufeis formation processes in various natural and climatic conditions of the Arctic zone has been noted (Morse and Wolfe, 2015; Alekseev, 2016; Crites et al., 2020). Well-identified on satellite images, aufeis can serve as indicators of changes in water exchange processes in the cryolithozone (Makarieva et al., 2019; Crites et al., 2020; Gagarin et al., 2020).

At present, routine interdisciplinary observations of aufeis processes are practically absent both in Russia and in the rest of the world despite the study of individual aufeis in central and southern Yakutia (Gagarin, 2012; Gagarin et al., 2020).

The Anmangynda aufeis is located in the basin of the Anmangynda River close to $155-159 \mathrm{~km}$ of the Tenka highway (Magadan region), $30 \mathrm{~km}$ southeast of the town of Ust-Omchug. The elevation of the Anmangynda river watershed ranges from 700 to $1850 \mathrm{~m}$. The study area is characterized by harsh winters and short summers. The average air temperature in July and January at the weather station Ust-Omchug is $+10.7^{\circ} \mathrm{C}$ and $-27.7^{\circ} \mathrm{C}$, respectively $(1966-2012)$. The absolute minimum reaches $-58^{\circ} \mathrm{C}$. The average annual precipitation is $375 \mathrm{~mm}$ (Ust-Omchug). The area is in the zone of continuous permafrost, sometimes interrupted by talik zones. The thickness of permafrost reaches $200 \mathrm{~m}$, deeper along watershed divides and shallower in river valleys (Bukaev, 1966).

In 1962, studies of the aufeis regime in the Anmangynda river basin were organized in order to investigate the dynamics of aufeis processes. The research included determining the size and volume of aufeis; mapping aufeis and fixing aufeis formations; study of the processes of runoff formation and the influence of climatic factors on the aufeis regime; study of the hydrochemical composition of surface waters (Bukaev, 1966; Lebedev and Ipatieva, 1980).

The catchment of the Anmangynda River is representative of Northeast Russia, and the Anmangynda aufeis is the only research plot in the world with long-term observations, including the dynamics of area and volume of the aufeis field.

\section{Prospects for comprehensive interdisciplinary research}

Different Earth sciences traditionally focus on individual components of a single natural system even though water exchange processes are the basis for the functioning of the 
cryolithozone. The complexity of the processes under consideration, combined with water and heat flows, necessitates an interdisciplinary scientific approach (Blöschl et al., 2019; Yang, 2020).

In this paper, we offer a vision for organizing complex research to assess and project the changes in the conditions of underground and surface water interaction in natural and disturbed conditions in the river basins of the cryolithozone of the Northeast, including for solving applied problems, based on permafrost, hydrology, hydrogeology, landscape science and geophysics with applications of remote sensing and field research integrated through mathematical modeling methods (Fig. 2).

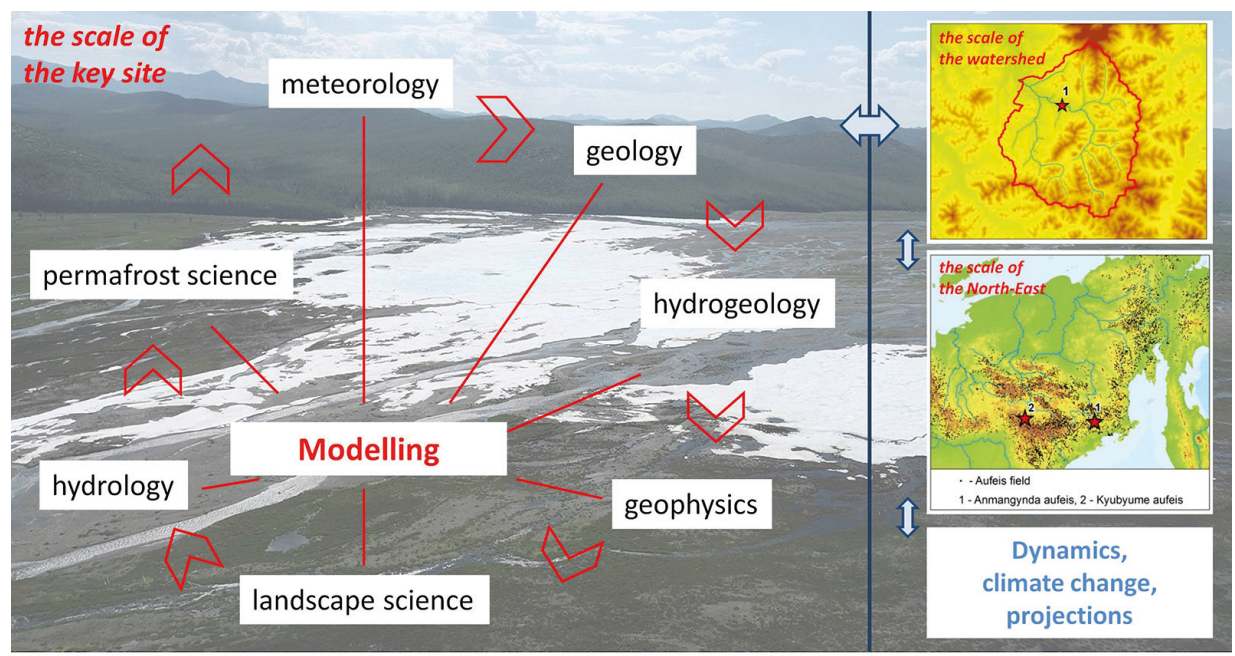

Fig. 2. The outline of interdisciplinary research. (Digital elevation model obtained from the site (USGS Data Site, n. d.) was used as a geographic basis for building maps.)

Mapping permafrost landscapes will allow us to establish their diversity, select key sites for the first phase of the project, both in natural conditions and in valleys modified by gold mining activities. This part of the study will be implemented based on open satellite data, verified for the research tasks during field work. A complex of geophysical surveys and drilling of wells for the organization of temperature and hydrogeological monitoring of groundwater will be carried out in key areas, and a network of gauging stations will be created to monitor the hydrological characteristics of rivers. Hydrogeochemical and isotope studies will also be carried out. Hydrological modeling will link all aspects of the research, as well as be used to assess the current state of the system and forecast changes in water exchange characteristics.

\subsection{The use of satellite data and unmanned aerial vehicles for mapping natural and anthropogenic disturbed landscapes}

Remote research methods traditionally include satellite imagery (for example, high-resolution Sentinel-2/MSI images or archives of satellite images of the Landsat mission) and use unmanned aerial vehicles to create detailed orthophotos with reference to coordinates. Analysis of high-resolution satellite images is used to identify characteristic 

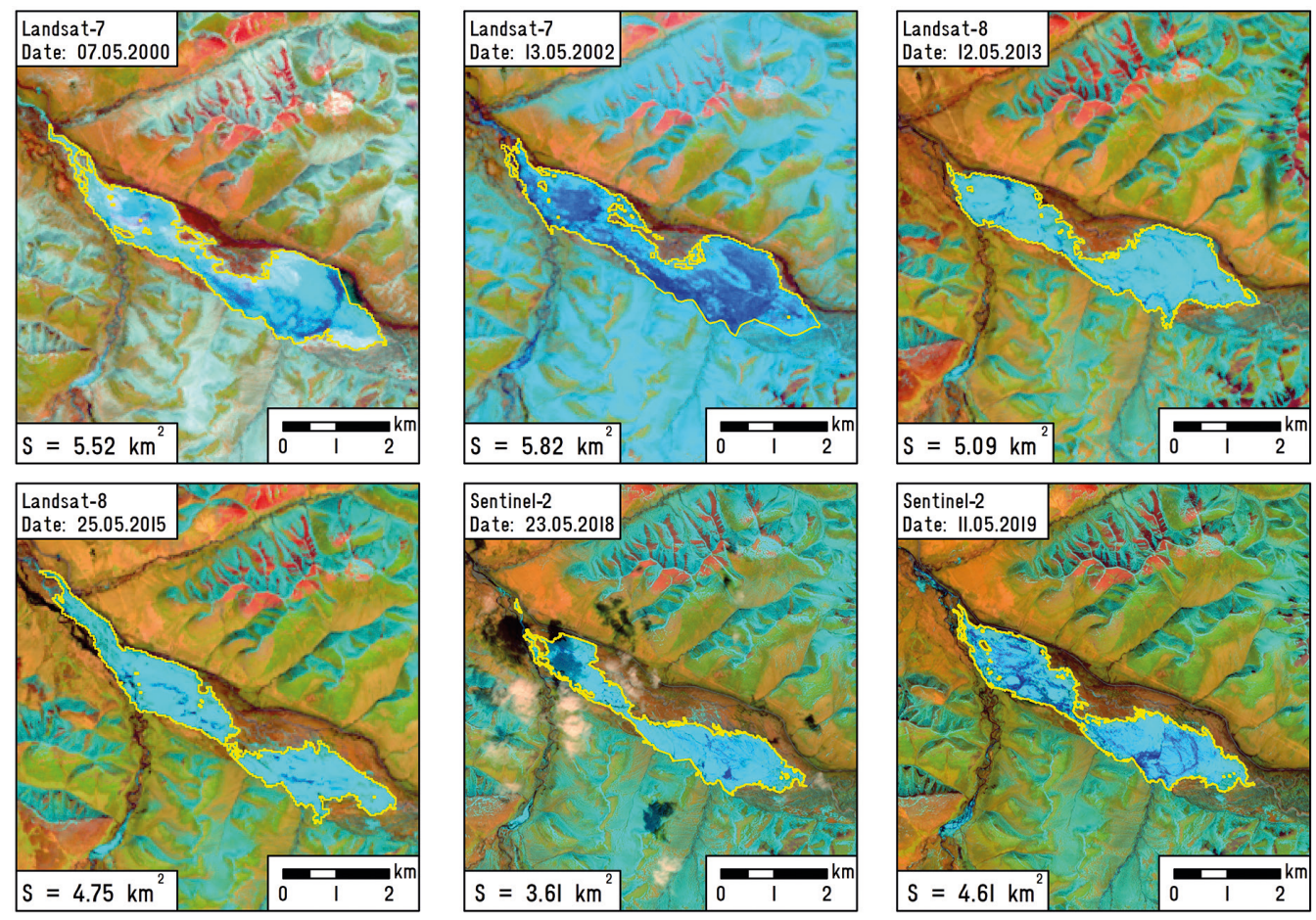

Fig. 3. An example of the use of satellite data in the studying inter-annual dynamics of the Anmangynda aufeis (Landsat- 8 and Sentinel-2 images). Compiled by the authors

types of terrain (including those disturbed, for example, by the gold mining industry) and key areas where equipment is installed and monitored (Joria and Jorgenson, 1996; Virtanen et al., 2004; Fraser et al., 2012). The terrain can be evaluated in terms of the transformation of natural landscapes as a result of climate warming or human activities based on the analysis of changes of spectral characteristics (Kirpotin et al., 2008; Kravtsova and Bystrova, 2009; Jones and Arp, 2015; Swanson, 2019). An example of such use of remote sensing methods is the study estimating the long-term dynamics of the aufeis area based on Landsat images and historical data (Makarieva et al., 2019a; 2019b) (Fig. 3).

\subsection{Geophysical research to establish permafrost-geological and hydrogeological structure of the study area}

It is necessary to conduct geophysical studies aimed at establishing tectonic disturbances for the selected key sites, which may be the underground source of aufeis feeding. Geophysical studies can also help determine the configuration and thickness of permafrost and talik zones (Gagarin, 2012; Olenchenko et al., 2017; Gagarin et al., 2019). It is advisable to use the methods of geo-radiolocation, electrical tomography, contactless electrical profiling, and near-field formation sensing to solve geological-structural and geocryological problems (Khristoforov, 2018; Gagarin et al., 2019; Olenchenko et al., 2019). A comprehensive analysis of the results of multi-scale geophysical studies will significantly reduce the ambiguity of interpretation of geophysical data. Drilling operations must 
be carried out in the study area to verify the geophysical data. Boreholes can also be used to establish the geological structure and composition of rocks, determine their thermal and water-physical properties. Deep boreholes are aimed at studying the hydrogeological characteristics of groundwater and determining the values of annual heat of talik zones, and shallow boreholes can be used to observe changes in the thickness of the active layer in the characteristic landscapes of key sites.

\subsection{Monitoring hydrometeorological, hydrogeological, isotopic and geochemical characteristics of the natural environment}

Hydrometeorological observations include the measurement of both meteorological characteristics and elements of the water balance of key sites. Hydrological monitoring also includes regular sampling of water and ice to determine their hydrochemical and isotopic compositions in order to determine the genesis of natural waters and thus the processes of water exchange (Aggarwal et al., 2005; Ekaykin, 2016). Hydrogeological monitoring will consist of routine measurements of the groundwater level in specially equipped boreholes, their temperature and mineralization, with parallel periodic sampling for hydrochemical and isotopic compositions. We will carry out aufeis measurement work to obtain morphometric parameters of aufeis (Bukaev, 1966; Lebedev and Ipatieva, 1980).

\subsection{Landscape field research}

A permafrost-landscape survey is carried out within key sites based on remote sensing results and includes a field description of the selected landscapes, considering their permafrost-geological features, soil and vegetation cover, snow accumulation features, etc. (Alekseev, 2005). The traditional field route observations can be used, with GPS tracking of observation points and creation of landscape maps and profiles for this purpose.

\subsection{Modeling runoff formation processes and projections of changes as a result of climate change and human activity}

Mathematical modeling links all aspects and results of the above studies into a single system describing hydrological and permafrost-hydrogeological conditions, and is also used to assess the current state and forecast changes in water exchange characteristics, dynamic groundwater storage in the region, water-ice regime of rivers in a changing climate, transport, energy and industrial development of the territory (Bolton, 2006; Pomeroy et al., 2007; Schramm et al., 2007; Fang et al., 2013; Fang and Pomeroy, 2020; Marsh et al., 2020). Generalization and prediction of the interaction of permafrost, surface and underground runoff at local and regional levels are possible only based on mathematical models that adequately describe both the formation of the temperature field and the hydrological cycle in various permafrost landscapes and hydrogeological conditions.

Traditionally, geocryology, hydrology and hydrogeology have developed various approaches to modeling natural processes in the cryolithozone. For example, geocryology usually models environmental parameters such as temperature, permafrost distribution, and depth of thawing and freezing. Water filtration, soil moisture, surface and underground runoff are considered factors of temperature field formation and are practically not considered in calculations (Sosnovsky, 2006; Malevsky-Malevich et al., 2007). Hy- 
drological and hydrogeological models for the permafrost zone do not consider the connection between underground and river runoff. The simplified scheme of modeling the processes of flow formation in permafrost and methods of parameter calibration that do not correspond to the observed natural phenomena, do not make it possible to obtain reasonable projections of changes in the hydrological regime and the state of permafrost in the future.

In this study, monitoring data and geochemical and geophysical analysis will be used to determine the role of underground recharge in the formation of river flow, including the time of water exchange and water reserves in underground horizons. The new field data obtained will become the basis for improving the algorithms and methods for parameterizing the hydrological model. After verification of the model, based on historical and newly obtained observational data, model experiments will be carried out to assess the impact of taliks and permafrost on ground and surface runoff, as well as projections of the possible consequences of climate change on taliks, permafrost and river flow in the region.

Mathematical modelling of soil temperature, active layer properties and dynamics, flow formation and interactions between ground and surface water will be performed by means of the process-based hydrological model Hydrograph (Vinogradov et al., 2011, Semenova et al., 2013). The model has proved to be a reliable tool for the study and forecasting of hydrological processes in the permafrost zone (Semenova et al., 2013). The model algorithms combine physically-based and conceptual approaches for the description of hydrological processes. The main parameters of the model are the physical properties of landscapes that may be measured in nature and are classified according to the types of soil, vegetation and other characteristics. The method for modeling heat dynamics in soil is integrated into the Hydrograph model. Also, the approaches are proposed to estimate thermal conductivity and heat transfer of calculation soil layers in the conditions of soil freezing/thawing and variable soil moisture. Physical properties of the materials composing the soil profile, such as density, porosity, thermal conductivity and thermal capacity, the maximum water holding capacity, are used as the model parameters (Semenova et al., 2014; Lebedeva et al., 2015).

Data obtained at representative sites can become the main source of information about processes occurring in poorly studied remote areas of the cryolithozone (Semenova et al., 2013). Based on such data, the parameters of the developed model will be estimated, their individual elements will be verified, and new modeling systems will be built.

\section{Reconnaissance and implementation of the first stage of the research}

In July and September 2020, the authors conducted two reconnaissance surveys in Northeast Russia to investigate the possibility of organizing research and restoring monitoring of geocryological and hydrological processes. The reconnaissance survey included the field study of the Anmangynda aufeis, the installation of basic equipment at the Kolyma Water-Balance Station, remote sensing survey of the Kyubume aufeis in eastern Yakutia and brief field surveys of the aufeis fields along the Tenka and Kolyma highways.

The landscape profiling of the Anmangynda aufeis glade was performed to assess the permafrost-hydrogeological conditions; special attention was paid to the description of vegetation cover, properties of rocks composing the glade and geocryological phenomena. The conducted landscape studies made it possible to establish the features of the forma- 


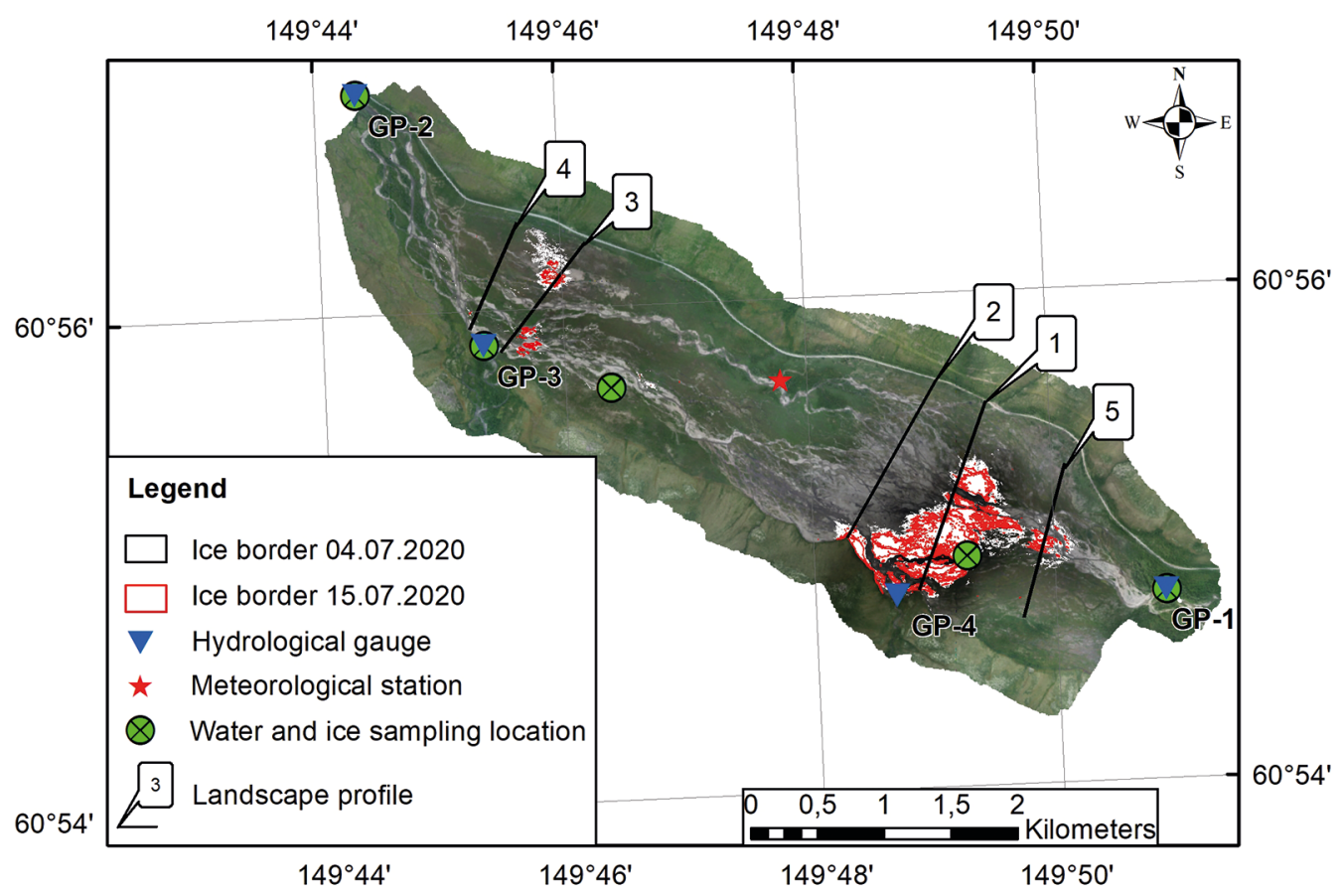

Fig. 4. The orthophoto of the Anmangynda aufeis (resulting from the field research in July, 2020)

tion of aufeis, indirectly determine the presence of taliks, assess the species composition of vegetation, identify the places of discharge of groundwater, discover new mechanisms of transportation and accumulation of alluvial sediments.

Quantitative assessment of changes in the area of the aufeis was obtained for the same period based on remote sensing data from an unmanned aerial vehicle. The area of the aufeis field decreased from 0.65 to $0.31 \mathrm{~km}^{2}$ from July 4 to July 15 (Fig. 4). The maximum area of the Anmangynda aufeis observed in spring before the start of ablation may reach up to 5-6 $\mathrm{km}^{2}$. By September 16 the aufeis had melted completely. The intensity of ice melting at representative sites of the Anmyngynda aufeis was calculated, the maximum total and daily values of which for the period from July 10 to July 18 were 68.6 and $7.7 \mathrm{~cm} /$ day, respectively. Isotopic and hydrochemical analysis of waters from various sources was also performed to determine the genesis of the waters that formed the aufeis. The analysis of the samples collected showed that the water is ultra-fresh and belongs to a slightly acidic environment; the Olchan River (left tributary of the Anmangynda River) is enriched with $\mathrm{Ca}^{2+}$ and $\mathrm{SO}_{4}^{2-}$. Based on field observations, the water balance of the Anmangynda river basin was assessed considering the aufeis meltflow. From July 4 to 15 total rainfall was $30 \mathrm{~mm}$, river flow amounted to $27 \mathrm{~mm}$, and aufeis inflow was about $3-5 \%$ of total river runoff.

At the Kolyma Water-Balance Station, a set of data loggers were installed to record (1) the water level and temperature in the Kontactovy creek, (2) precipitation at the highest part of the watershed at the Morozova creek, which presents the goltsy landscape. These data have not been processed yet. 
The final point of the survey route was the Kyubyume aufeis. An orthophotoplan of the aufeis glade was compiled, and water samples were taken for isotopic and hydrochemical analysis. Unlike the Anmangynda aufeis, the Kyubyume aufeis has not melted completely and some parts of the aufeis remained throughout the warm season to reform in the cold season. This shows that aufeis phenomena are very different and several field sites should be chosen for investigation to get a wider understanding of the processes and the factors influencing them.

Currently, field observations continue, obtaining meteorological and hydrological information on the Anmangynda aufeis, and the data are being prepared for the implementation of the second stage, which includes the interdisciplinary studies listed above.

\section{Discussion and conclusion}

Russia has seen an increase in the temperature of permafrost and the thickness of the seasonal thaw layer in recent decades (Romanovsky et al., 2010; Garagulya et al., 2012; Sherstyukov and Sherstyukov, 2015). Climate warming and degradation of permafrost are leading to the transformation of the natural system, but the mechanisms of change are poorly understood. However, over the past 30 years, Russia has significantly lagged behind other Arctic countries in the field of research on water exchange processes in the cryolithozone (Laudon et al., 2017). Thus, to study the mechanisms of interaction and forecast water exchange of underground and surface waters in the cryolithozone of Northeast Russia, it is necessary to conduct complex interdisciplinary studies.

The solution of the problem and generalization of the results is possible only at the regional scale, considering the specific features of climate, geological structure, topography, geocryological characteristics, and landscapes. To a large extent, it depends on the availability of field data of joint observations of the dynamics of the permafrost, hydrogeological conditions in the catchments and river flow, which allow the identification of the mechanisms of their interaction, and also the ability to track the dynamics in the historical perspective, to justify the forecast of changes in the future. The scientific novelty of the proposed research is as follows:

Comprehensive monitoring of permafrost, hydrogeological conditions and runoff formation processes will be organized in Northeast Russia at several key sites for the first time in 30 years. The representativeness of the selected key sites will allow the transfer of the research results to the regional level, and the approaches developed will be relevant for other regions of the cryolithozone.

Newly organized regime observations at the reference aufeis polygon will make it possible to study the dynamics of aufeis-forming sources and calculate the dynamic reserves of underground water. Geophysical and hydrogeological data will be used to establish the relationship between the types and structure of the hydrographic network and the location of sub-stream taliks. This will make it possible to assess the intensity and transformation of water exchange processes as a result of changes due to climate change and anthropogenic activity.

For the first time, quantitative estimates of the share of underground flow in general runoff during various phases of the water regime will be calculated for the Northeast, based on monitoring data, isotope geochemistry, and the developed water exchange model. 
For the first time, an atlas of permafrost landscapes will be compiled based on remote sensing data, including landscapes disturbed by the activities of gold mining companies. Based on the published and newly obtained data, the atlas will allow for the systematic assessment of predicted changes in water exchange in various types of landscapes depending on the response of permafrost and taliks to climate change. It will also allow the assessment of the degree of transformation of the water exchange system within anthropogenic disturbed areas, as well as their contribution to changes in the hydrological and ecological regime of rivers in Northeast Russia.

For the first time, the projections of changes in the regime and geochemical composition of natural waters will be developed for the Northeast region as a result of the transformation of the water exchange structure due to climate warming and human activity.

The possibility of implementing the listed prospects for the development of scientific sites in the cryolithozone of Northeast Russia is determined by the following factors.

- Availability of continuous long-term observations on the permafrost, hydrogeological conditions, and river flow at selected key sites during the historical period, which will allow us to track the dynamics of permafrost characteristics, hydrogeological conditions and flow and link them to climate changes.

- Traditional methods of studying the state of thawed and frozen zones (monitoring, landscape indication, drilling) will be supplemented by detailed geophysical surveys, methods of isotope and hydrochemistry, automated observations with high time resolution and mathematical modeling.

- Use of modeling methods that explicitly consider the dynamics of the active layer and its variable states in hydrological calculations. New algorithms and parametrization describing the mechanisms of communication between ground and surface waters will be developed together with permafrost scientists based on monitoring data.

- Availability of infrastructure and human resources for the organization of fullfledged comprehensive monitoring of research objects.

- Interdisciplinarity and experience of the team.

- The research is supported by the government of the Magadan region at regional and local scales. They are ready to cooperate and help in the implementation of the project. Contacts with municipal authorities were established and positive feedback was received from residents during the expedition.

The proposed program requires a strong scientific base and the prospects can be realized only by attracting young scientific personnel, which necessitates close interaction between research institutes and universities across Russia.

The authors are grateful to the local authorities of the Tenka district of the Magadan region (represented by the head of the Tenka district D. A. Revutskiy) for their support in organization of the research. We also thank two anonymous reviewers who provided constructive comments to the manuscript allowing for its significant improvement.

\section{References}

Åkerman, H. and Johansson, M. (2008). Thawing permafrost and thicker active players in sub-arctic Sweden. Permafrost and Periglacial Processes, 19 (3), 279-292. 
Alekseyev, V. (2005). Landscape Indication of Aufeis Phenomena. Novosibirsk: Siberian Branch of Nauka Publ. (In Russian)

Alekseev, V. (2016). Long-term variability of the spring taryn-aufeises. Led i sneg, 56 (1), 73-92.

Federal service for hydrometeorology and environmental monitoring (Roshydromet). (2008). Assessment report on climate change and its consequences in Russian Federation [online]. Available at: http:// climate2008.igce.ru/v2008/pdf/resume_ob_eng.pdf [Accessed Sep. 06, 2020].

Blöschl, G., et al. (2019). Changing Climate Both Increases and Decreases European River Floods. Nature 573, 108-111. https://doi.org/10.1038/s41586-019-1495-6

Bolton, W. (2006). Dynamic modeling of the hydrologic processes in areas of discontinuous permafrost. $\mathrm{PhD}$ thesis. University of Alaska Fairbanks.

Brutsaert, W. and Hiyama, T. (2012). The determination of permafrost thawing trends from long-term streamflow measurements with an application in Eastern Siberia. Journal of Geophysical Research, 117, D22110. https://doi.org/10.1029/2012JD018344

Bukaev, N. (1966) The main regularities of the regime of giant aufeis in the upper reaches of the Kolyma river (on the example of the Anmangynda aufeis). Kolyma, 4, 9-12. (In Russian)

Burn, C. and Nelson, F. (2006). Comment on "A projection of severe near-surface permafrost degradation during the $21^{\text {st }}$ century" by David M. Lawrence and Andrew G. Slater. Geophysical Research Letters, 33, L21503. https://doi.org/10.1029/2006GL027077

Crites, H., Kokeji, S. and Lacelle, D. (2020). Icings and groundwater conditions in permafrost catchments of northwestern Canada. Sci Rep., 10, 3283.

Ekajkin, A. (2016). Stable water isotopes in glaciology and paleogeography. St. Petersburg: AARI Publ. (In Russian)

Ensom, T., Alekseev, V., Kane, D., Makarieva, O., Marsh, P. and Morse, P. (2020). The distribution and dynamics of aufeis in permafrost regions. Permafrost and Periglacial Process, 1-13. http://doi. org/10.1002/ppp.205

Fang, X., Pomeroy, J., Ellis, C., MacDonald, M., DeBeer, C. and Brown, T. (2013). Multi-variable evaluation of hydrological model predictions for a headwater basin in the Canadian Rocky Mountains. Hydrology and Earth System Sciences, 17, 1635-1659.

Fang, X. and Pomeroy, J. (2020). Diagnosis of future changes in hydrology for a Canadian Rockies headwater basin. Hydrology and Earth System Sciences, 24, 2731-2754. https://doi.org/10.5194/hess-24-2731-2020

Fraser, R., McLennan, D., Ponomarenko, S. and Olthof, I. (2012). Image-based predictive ecosystem mapping in Canadian Arctic Parks, International Journal of Applied Earth Observation and Geoinformation, 14, 129-138. https://doi.org/10.1016/j.jag.2011.08.013

Fedorov, A., Ivanova, R., Perk, H., Hiyama, T. and Iijima, Y. (2014). Recent air temperature changes in the permafrost landscapes of northeastern Eurasia, Polar Science, 8 (2), 114-128. http://dx.doi. org/10.1016/j.polar.2014.02.001

Gagarin, L. (2012). Research of thermo-suffosion processes in Central Yakutia. Nauka i obrazovanie, 2, 41-45. (In Russian)

Gagarin, L., Bazhin, K., Olenchenko, V., Ogonerov, V. and Cinbaj, V. (2019). Revealing potential thermosuffosional soil loosening sites along A-360 Lena Federal highway, Central Yakutia. Kriosfera Zemli, 23 (3), 61-68. (In Russian)

Gagarin, L., Qingbai, W., Melnikov, A., Volgusheva, N., Tananaev, N., Jin, H., Zhang, Z. and Zhizhin, V. (2020). Morphometric analysis of groundwater icings: Intercomparison of estimation techniques. Remote Sensing, 12 (4), 692. https://doi.org/10.3390/rs12040692

Garagulja, L., Gordeeva, G. and Ospennikov, E. (2012). Role of geocryological processes in the formation and dynamics of geocryological ecosystems. Kriosfera Zemli, (16) 4,31-41. (In Russian)

Grebenets, V., Streletskiy, D. and Shiklomanov, N. (2012). Geotechnical safety issues in the cities of Polar Regions. Geography, Environment, Sustainability, 5 (3), 104-119.

Harris, D., Cheung, C., Stawarz, Ł., Biretta, J. and Perlman, E. (2009). Hard X-ray Emission from the M87 AGN Detected with NuSTAR. The Astrophysical Journal, 699, 305.

Hinzman, L., Deal, C., Mcguire, A., Mernild, S., Polyakov, I. and Walsh, J. (2013). Trajectory of the Arctic as an integrated system. Ecological Applications, 23 (8), 1837-1868. https://doi.org/10.1890/11-1498.1

Holmes, R., Coe, M., Fiske, G., Gurtovaya, T., McClelland, J., Shiklomanov, A., Spencer, R., Tank, S. and Zhulidov, A. (2012). Climate Change Impacts on the Hydrology and Biogeochemistry of Arctic Rivers. 
In: Climatic Change and Global Warming of Inland Waters: Impacts and Mitigation for Ecosystems and Societies. Chichester, UK: John Wiley and Sons, Ltd. https://doi.org/10.1002/9781118470596.ch1

Aggarwal, P. K., Gat, J.R. and Froehlich, K. F. (eds.) (2005). Isotopes in the Water Cycle Past, Present and Future of a Developing Science. Netherlands: Springer.

Jepsen, S., Voss, C., Walvoord, M., Minsley, B. and Rover, J. (2013). Linkages between lake shrinkage/ expansion and sublacustrine permafrost distribution determined from remote sensing of interior Alaska, USA. Geophysical Research Letters, 40, 882-887, https://doi.org/10.1002/grl.50187

Jones, B. and Arp, C. (2015). Observing a catastrophic thermokarst lake drainage in northern Alaska. Permafrost and Periglacial Processes, 26 (2), 119-128.

Joria, P. and Jorgenson, J. (1996). Comparison of three methods for mapping tundra with Landsat digital data. Photogrammetric Engineering and Remote Sensing, 62, 163-169.

Kirpotin, S., Kolmakova, M., Polishchuk, Yu., Zakharova, E., Shirokova, L., Pokrovsky, O. and Dupre, B. (2008). One of the possible mechanisms of thermokarst lakes drainage in West-Siberian North. International journal of environmental studies, 65 (5), 631-635. https://doi.org/10.1080/00207230802525208

Kravcova, V. and Bystrova, A. (2009). Changes in thermokarst lake size in different regions of Russia for the last 30 years. Kriosfera Zemli, 13 (2), 16-26. (In Russian)

Khristoforov, I., Omelyanenko, A., Omelyanenko, P. and Overduin, P. (2018). Displacement Frequency Characteristics of Direct Transmission of GPR Signals in Borehole Measurements. GPR 2018: Proceedings of the Ground Penetrating Radar Conference. https://doi.org/10.1109/ICGPR.2018.8441543

Lawrence, D. and Slater, A. (2005). A projection of severe near-surface permafrost degradation during the $21^{\text {st }}$ century. Geophysical Research Letters, 32, L24401. https://doi.org/10.1029/2005GL025080

Laudon, H., Spence, Ch., Buttle, J., Carey, S., McDonnell, J., McNamara, J., Soulsby, Ch. and Tetzlaff, D. (2017). Save northern high-latitude catchments. Nature Geoscience, 10 (5), 324-325.

Lebedeva, L., Bazhin, K., Hristoforov, I., Abramov, A., Pavlova, N., Efremov, V.S., Ogonerov, V.V., Tarbeeva, A.M., Fedorov, M.P., Nesterova, N.V. and Makarieva, O.M. (2019). Suprapermafrost subaerial taliks, Central Yakutia, Shestakovka River basin. Kriosfera Zemli, 23 (1), 40-50. (In Russian)

Lebedev, V. and Ipateva, A. (1980). Anmangynda aufeis, its regime and role in water balance of the river basin. In: Trudy DVNIGMI. Vol.84. Hydrometeorological Research and Forecasting. Leningrad: Gidrometeoizdat Publ., 86-93. (In Russian)

Lebedeva, L., Semenova, O. and Vinogradova, T. (2015). Calculation of seasonal thawing depth in different landscapes of the Kolyma water-balance station by means of hydrological model "Hydrograph". Part 2. Kriosfera Zemli, 19 (2), 35-44. (In Russian)

Makarieva, O., Shikhov, A., Ostashov, A. and Nesterova, N. (2019). Icings of the Indigirka river basin according to the recent Landsat satellite images and historical data. Ice and Snow, 59 (2), 201-212. https://doi.org/10.15356/2076-6734-2019-2-388 (In Russian)

Makarieva, O., Shikhov, A., Nesterova, N. and Ostashov, A. (2019). Historical and recent aufeis in the Indigirka River basin (Russia). Earth System Science Data, 11, 409-420. https://doi.org/10.5194/essd11-409-2019

Makarieva, O., Nesterova, N., Lebedeva, L. and Vinogradova, T. (2019). Modeling runoff formation processes in the high-mountain permafrost zone of Eastern Siberia (a case study of the Suntar-Hayata Range). Geography and natural resources, 1, 178-186.

Malevskij-Malevich, S., Molkentin, E., Nadezhina, E., Pavlova, T. and Semioshina, A. (2007). Modelling and analysis of opportunities for the experimental control of the evolution of permafrost thermal conditions. Kriosfera Zemli, 11 (1), 29-36. (In Russian) Available at: http://www.izdatgeo.ru/pdf/ krio/2007-1/29.pdf [Accessed Mar. 04, 2021].

Marsh, C., Pomeroy, J. and Wheater, H. (2020). The Canadian Hydrological Model (CHM) v1.0: a multiscale, multi-extent, variable-complexity hydrological model - design and overview. Geoscientific Model Development, 13, 225-247. https://doi.org/10.5194/gmd-13-225-2020

Morse, P. and Wolfe, S. (2015). Geological and meteorological controls on icing (aufeis) dynamics (1985 to 2014) in subarctic Canada. Geophysical Research: Earth Surface, 120, 1670-1686.

Olenchenko, V., Gagarin, L., Khristoforov, I., Kolesnikov, A. and Efremov, V. (2017). The Structure of a site with thermo-suffosion processes within Bestyakh terrace of the Lena river, according to geophysical data. Kriosfera Zemli, 21 (5), 16-26. 
Olenchenko, V., Cibizov, L., Kartozija, A. and Esin, E. (2019). Electrical resistivity tomography of drained thermokarst lake basin on Kurungnakh island in the Lena river delta. Problemy Arktiki i Antarktiki, 65 (1), 92-104. (In Russian)

Osterkamp, T. (2005). The recent warming of permafrost in Alaska. Global Planet Change, 49, 187-202.

Pomeroy, J., Gray, D. and Brown, T. (2007). The cold regions hydrological model: a platform for basing process representation and model structure on physical evidence. Hydrological Processes, 21, 26502667.

Quinton, W., Hayashi, M. and Chasmer, L. (2011). Permafrost-thaw-induced land-cover change in the Canadian subarctic: Implications for water resources, Hydrological Processes, 25 (1), 152-158.

Romanovsky, V., Smith, S. and Christiansen, H. (2010). Permafrost thermal state in the polar Northern Hemisphere during the International Polar Year 2007-2009: A synthesis, Permafrost Periglacial Process, 21, 106-116. https://doi.org/10.1002/ppp.689

Schramm, I., Boike, J., Bolton, W. and Hinzman, L. (2007). Application of TopoFlow, a spatially distributed hydrological model, to the Imnavait Creek watershed, Alaska. Geophysical Research, 112, G04S46. https://doi.org/10.1029/2006JG000326

Selin, V., Vasilev, V. and Shirokova, L. (2011). Russian Arctic: geography, economy, zoning. Apatity: Kola Scientific Center, RAS. (In Russian)

Semenova (Makarieva), O., Lebedeva, L. and Vinogradov, Yu. (2013). Simulation of subsurface heat and water dynamics, and runoff generation in mountainous permafrost conditions, in the Upper Kolyma River basin, Russia. Hydrogeology Journal, 21 (1), 107-119. https://doi.org/10.1007/s10040-012-0936-1

Semenova (Makarieva), O., Vinogradov, Yu., Vinogradova, T. and Lebedeva, L. (2014). Simulation of Soil Profile Heat Dynamics and their Integration into Hydrologic Modelling in a Permafrost Zone. Permafrost and Periglacial Processes, 25 (4), 257-269. https://doi.org/10.1002/ppp.1820

Shepelev, V. (2011). Suprapermafrost Water in the Cryolithozone. Novosibirsk: Geo Publ. (In Russian)

Sherstyukov, A. and Sherstyukov, B. (2015). Spatial features and new trends in thermal conditions of soil and depth of its seasonal thawing in the permafrost zone. Russian Meteorology and Hydrology, 40, 73-78. https://doi.org/10.3103/S1068373915020016

Sosnovsky, A. (2006). Mathematical modelling of the influence of snow cover thickness on degradation of permafrost at climate warming. Kriosfera Zemli, 10, 83-88. (In Russian) Available at: http://www. izdatgeo.ru/pdf/krio/2006-3/83.pdf [Accessed Mar. 04, 2021].

Streletskiy, D., Shiklomanov, N. and Hatleberg, E. (2012). Infrastructure and a Changing Climate in the Russian Arctic: A Geographic Impact Assessment. Proceedings of the 10th International Conference on Permafrost, 1, 407-412.

Swanson, D. (2019). Thermokarst and precipitation drive changes in the area of lakes and ponds in the National Parks of northwestern Alaska, 1984-2018. Arctic Antarctic and Alpine Research, 51, 265-279.

Tananaev, N., Makarieva, O. and Lebedeva, L. (2016). Trends in annual and extreme flows in the Lena River basin, Northern Eurasia. Geophysical Research Letters, 43,20136. https://doi.org/10.1002/2016GL070796

Tetsuya, H., Kazuyoshi, A., Kolesnikov, A., Gagarin, L. and Shepelev, V. (2013). Estimation of the residence time of permafrost groundwater in the middle of the Lena River basin, Eastern Siberia. Environmental Research Letters, 8 (3). Available at: https://iopscience.iop.org/article/10.1088/1748-9326/8/3/035040 [Accessed Mar. 04, 2021].

Tregubov, O., Gartsman, B., Lebedeva, L., Nuteveket, M., Tarbeeva, A., Uyagansky, K., Shekman, E. and Shepelev, V. (2020). Landscape-permafrost conditions and factors of summer runoff formation of small coastal lowland rivers. E3S Web Conf. Vol.163 IV Vinogradov Conference "Hydrology: from Learning to Worldview" in Memory of Outstanding Russian Hydrologist Yury Vinogradov". https://doi. org/10.1051/e3sconf/202016305015

USGS Data Site (n. d.). [online] Available at: https://earthexplorer.usgs.gov/ [Accessed May 31, 2020].

Virtanen, T., Mikkola, K. and Nikula, A. (2004). Satellite image based vegetation classification of a large area using limited ground reference data: A case study in the Usa basin, north-east European Russia. Polar Research, 23, 51-66. https://doi.org/10.3402/polar.v23i1.6266

Walvoord, M. and Striegl, R. (2007). Increased groundwater to stream discharge from permafrost thawing in the Yukon River basin: Potential impacts on lateral export of carbon and nitrogen. Geophysical Research Letters, 34 (12). https://doi.org/10.1029/2007GL030216 
Yang, D. and Kane, D. (2020). Arctic Hydrology, Permafrost and Ecosystems. Springer. Available at: https:// link.springer.com/book/10.1007/978-3-030-50930-9 [Accessed Mar. 04, 2021].

Yoshikawa, K. and Hinzman, L. (2003). Shrinking thermokarst ponds and groundwater dynamics in discontinuous permafrost near council, Alaska. Permafrost Periglacial Process, 14 (2), 151-160.

Received: October 17, 2020

Accepted: December 14, 2020

Contact information:

Olga M.Makarieva — omakarieva@gmail.com

NataliiaV.Nesterova — nnesterova1994@gmail.com

Andrey A.Ostashov - andrey.ostashov@gmail.com

Anastasia A.Zemlyanskova - anastasiazemlanskova@gmail.com

VladimirE.Tumskoy — vtumskoy@gmail.com

Leonid A. Gagarin - gagarinleo@yandex.ru

AlexeyA.Ekaykin — ekaykin@aari.ru

Andrey N.Shikhov - and3131@inbox.ru

VladimirV.Olenchenko _ olenchenkovv@yandex.ru

Ivan I.Khristoforov — zodik@mail.ru

\section{Перспективы развития комплексных междисциплинарных гидролого-мерзлотных исследований на Северо-Востоке России}

О. М. Макарьева ${ }^{1,2}$, Н. В. Нестерова ${ }^{1,2,3}$, А. А. Осташов ${ }^{1}$, А. А. Землянскова ${ }^{1,2}$, В.Е. Тумской ${ }^{4,7}$, Л. А. Гагарин ${ }^{4}$, А. А.Екайкин ${ }^{2,8}$, А. Н. Шихов ${ }^{6}$, В. В. Оленченко И. И. Христофоров ${ }^{4}$

${ }^{1}$ Институт мерзлотоведения им. П. И. Мельникова Сибирского отделения Российской Академии наук, Северо-Восточная научно-исследовательская мерзлотная станция, Российская Федерация, 685000, Магадан, ул. Портовая, 16

${ }^{2}$ Санкт-Петербургский государственный университет, Российская Федерация, 199034, Санкт-Петербург, Университетская наб., 7-9

${ }^{3}$ Государственный гидрологический институт, Российская Федерация, 199004, Санкт-Петербург, 2-я линия В. О., 23

${ }^{4}$ Институт мерзлотоведения им. П.И. Мельникова Сибирского отделения Российской Академии наук, Российская Федерация, 677010, Якутск, ул. Мерзлотная, 36

${ }^{5}$ Институт нефтегазовой геологии и геофизики им. А. А. Трофимука Сибирского отделения Российской Академии наук, Российская Федерация, 630090, Новосибирск, пр. Академика Коптюга, 3

${ }^{6}$ Пермский государственный национальный исследовательский университет, Российская Федерация, 614990, Пермь, ул. Букирева, 15

${ }^{7}$ Московский государственный университет имени М. В. Ломоносова, Российская Федерация, 119991, Москва, Ленинские горы, 1

8 Арктический и антарктический научно-исследовательский институт, Российская Федерация, 199397, Санкт-Петербург, ул. Беринга, 38

Для цитирования: Makarieva, O. M., Nesterova, N. V., Ostashov, A. A., Zemlyanskova, A. A., Tumskoy, V.E., Gagarin, L. A., Ekaykin, A. A., Shikhov, A. N., Olenchenko, V. V., Khristoforov, I. I. (2021). Perspectives of the development of complex interdisciplinary hydrological and geocryological research in the North-East of Russia. Вестник Санкт-Петербургского университета. Науки о Землe, 66 (1), 74-90. https://doi.org/10.21638/spbu07.2021.105

* Данная работа поддержана Русским географическим обществом (проект 26/2019-I) и Российским фондом фундаментальных исследований (проекты 19-55-80028, 19-35-90090 и 20-05-00666). 
Потепление климата и антропогенное воздействие приводят к разнонаправленным изменениям геокриологических условий в речных бассейнах Северо-Востока России, в том числе трансформации процессов водообмена между поверхностными и подземными водами. Это проявляется в сезонном перераспределении составляющих водного баланса, ускорении стаивания наледей, изменении соотношения типов природных вод в структуре речного стока. Возрастают природные и антропогенные риски, влияющие на безопасное и эффективное развитие инфраструктуры и социально-экономических процессов. Система наблюдений, сложившаяся в советский период, была практически разрушена в регионе. В работе предлагается видение организации комплексных междисциплинарных исследований по оценке и прогнозированию изменений условий взаимодействия подземных и поверхностных вод в естественных и нарушенных речных бассейнах криолитозоны Северо-Востока России, в том числе для решения прикладных задач, основанных на подходах мерзлотоведения, гидрологии, гидрогеологии, ландшафтоведения и геофизики с применением методов дистанционного зондирования и полевых исследований, интегрированных с помощью математического моделирования. Для достижения поставленной цели проведена идентификация естественных и нарушенных ландшафтов с использованием данных дистанционного зондирования Земли, выбраны ключевые районы для детальных исследований. На площадках проведены геофизические и буровые работы по установлению многолетнемерзло-гидрогеологических условий, оборудованы станции мониторинга для определения гидрогеологических, гидрометеорологических и геокриологических характеристик, включая отбор проб для изотопных и гидрогеохимических исследований. В качестве основных ключевых объектов предлагается использовать район Колымской водно-балансовой станции и полигон на Анмангындинской наледи, для которых имеются многолетние ряды наблюдений, проведенных в XX веке. Полевые данные станут основой для совершенствования математической модели формирования стока. Математическое моделирование позволит количественно проанализировать водный баланс рек с учетом различных факторов и дать прогноз водообеспеченности как для конкретных промышленных объектов, так и для региона в целом.

Ключевые слова: процессы водообмена, многолетняя мерзлота, речной сток, деятельный слой, талик, надмерзлотные воды, подземный сток, наледь, геофизика, дистанционное зондирование, математическое моделирование, мониторинг, изотопы, изменение климата, антропогенные возмущения, Северо-Восток России.

Статья поступила в редакцию 17 октября 2020 г. Статья рекомендована к печати 14 декабря 2020 г.

Контактная информация:

Макарьева Ольга Михайловна - omakarieva@gmail.com

Нестерова Наталия Вадимовна - nnesterova1994@gmail.com

Осташов Андрей Алексеевич - andrey.ostashov@gmail.com

Землянскова Анастасия Александровна - anastasiazemlanskova@gmail.com

Тумской Владимир Евгеньевич - vtumskoy@gmail.com

Гагарин Леонид Александрович - gagarinleo@yandex.ru

Екайкин Алексей Анатольевич - ekaykin@aari.ru

Шихов Андрей Николаевич - and3131@inbox.ru

Оленченко Владимир Владимирович — olenchenkovv@yandex.ru

Христофоров Иван Иванович - zodik@mail.ru 